\title{
Developing Number Theory Textbook to Improve Understanding of the Prospective Teachers' Concept
}

\author{
$1^{\text {st }}$ Istiqomah $^{1}, 2^{\text {nd }}$ KS Kuncoro ${ }^{2}, 3^{\text {rd }}$ DN Oktaviani ${ }^{3}, 4^{\text {th }}$ AA Sujadi ${ }^{4}$ \\ \{ istiqomah@ustjogja.ac.id ${ }^{1}$, kridasinggih.math@gmail.com ${ }^{2}$, dian85nataria@oktaviani ${ }^{3}$ \} \\ Universitas Sarjanawiyata Tamansiswa, J1. Kusumanegara No.157, Daerah Istimewa Yogyakarta ${ }^{124}$, \\ Universitas Pancasakti, J1. Halmahera No.KM 01, Tegal, Jawa Tengah ${ }^{3}$,
}

\begin{abstract}
The purpose of this study was to develop a number theory textbook in order to improve prospective teachers' understanding of concepts and describe the feasibility of teaching materials number theory. The type of research used is the research development, with the development model chosen is a development model that fits the procedure suggested by Borg and Gall which consists of 5 steps. The steps taken are product analysis to be developed, initial product development, expert validation, and product revision, limited field trials, and product revisions, main field trials, and final products. Data creation techniques using product validation techniques and product trials. This study focuses on the steps of analyzing products that are developed up to expert validation steps. The validator suggests that textbooks are very good in all three aspects with an average score of 4.62 on a scale of 5 and can be continued at the Small-scale Trial stage.
\end{abstract}

Keywords: research and development, textbook, number theory.

\section{Introduction}

Mathematics is the study of patterns and relatedness. Mathematics is not just a collection of numbers and various formulas that have nothing to do in everyday life, including the knowledge of numbers or numerology. Numbers in the journey are better known as the Number Theory.

Numbers are a mathematical concept used for enumeration and measurement. Symbols used to represent a number are called numbers or symbol numbers. Numbers are initially only used to remember the amount, but in its development after mathematicians add symbols and words that are appropriate for defining numbers, mathematics becomes very important for life and we cannot deny that in our daily lives we will always meet with numbers, because numbers are always needed in technology, science, economics or in the world of music, philosophy, and entertainment and many other aspects of life.

Understanding mathematical concepts are one of the most important things in learning. It made prospective teachers easier to solve problems because they would be able to connect and solve problems with the concept that they already understand. Conversely, if prospective teachers did not understand a concept given, prospective teachers will tend to experience difficulties in using and choosing certain procedures or operations and applying problemsolving concepts and algorithms. Recognizing the importance of understanding concepts in 
mathematics learning, the learning process needed to be planned in such a way that at the end of learning prospective teachers could understand the concepts they learn.

One effort to improve the understanding of mathematical concepts is to provide good teaching materials. Teaching material is one component of the learning system that plays an important role in helping prospective teachers achieve the expected learning outcomes[1][3]. High-quality teaching materials can contribute substantially to the quality of prospective teachers' learning experiences and prospective teachers outcomes [4]. Broadly speaking, teaching materials or learning materials contain knowledge, skills, and attitudes or values that prospective teachers must learn. Some examples of teaching materials include textbooks, dictates, handouts, and others.

In the lecture on Number Theory, there have been no textbooks that can be easily understood by prospective teachers whereas math textbooks play an important role in shaping instruction and learning methods for students and teachers using strategies[5][6]. During this time in the learning process, the Number Theory course still uses textbooks which are apparently quite difficult for prospective teachers to understand, both in terms of language and material presented. The impact is that prospective teachers find it difficult to understand the textbooks that have been used so that their learning achievement is less satisfying. Prospective teachers are still confused by the concept of division and its application. Whereas division is the core material in Number Theory, where this material underlies the next material.

The textbook that will be developed in this study is a textbook based on the concept of Tamansiswa teachings, its means discern (niteni), imitate (nirokke), and add (nambahi) often referred as $3 \mathrm{~N}$. According to Ki Hadjar Dewantara (KHD), in the learning process, prospective teachers must implement the potential by means of "niteni", "nirokke", and "nambahi"[7][9]. Niteni (discern) is an effort to seek clarity from an event or situation through observations in a clear and in-depth manner. Nirokke (imitate) is an activity imitating from what is seen, heard, felt in the form of examples or good examples. Whereas nambahi (add) is an activity that complements through innovation and creativity, which gives rise to new things. The concept of niteni, nirokke, and nambahi in its implementation is not something that can be separated from one another. One thing does not acknowledge another. But all three are integral in one activity so as to produce complete knowledge and higher order thinking skills.

\section{Methods}

This study used research and development (R\&D) based on the Borg and Gall model from various steps used and simplified by the Ministry of Education and Culture into five procedure steps including (1) analyzing the developed product, (2) developing initial product, (3) expert validation and revision, (4) small-scale trials and product revisions, (5) large-scale trials and product finalization [11]. Those five steps can be visualized in Figure 1.

The research subjects used as trial subjects were prospective teachers who took the Number Theory course in the 2017/2018 academic year. The object of this research is the development of a number theory textbook based on $3 \mathrm{~N}$ teachings to improve the conceptual understanding Department of Mathematics Education students. The place for product development was carried out in the Department of Mathematics Education Faculty of Teacher Training and Education University of Sarjanawiyata Tamansiswa, as well as a place for testing. Research time in Even Semester Academic Year 2017/2018. 


\begin{tabular}{|c|c|c|c|c|c|c|c|}
\hline $\begin{array}{l}\text { Curriculum analysis and } \\
\text { Semester Lesson Plan }\end{array}$ & \multicolumn{2}{|c|}{$\begin{array}{l}\text { Material } \\
\text { Analysis }\end{array}$} & \multicolumn{2}{|c|}{ Student Analysis } & \multicolumn{2}{|c|}{$\begin{array}{l}\text { Situation Analysis of } \\
\text { Class Conditions }\end{array}$} & $\begin{array}{l}\text { Product } \\
\text { Analysis }\end{array}$ \\
\hline \multicolumn{8}{|l|}{ 2. Developing Initial Product } \\
\hline \multicolumn{2}{|l|}{$\begin{array}{l}\text { Preparation stages: Look for } \\
\text { reference books, drawings, and } \\
\text { lecture material }\end{array}$} & \multicolumn{3}{|c|}{$\begin{array}{l}\text { Stages of preparation: } \\
\text { outline the contents of } \\
\text { teaching materials }\end{array}$} & \multicolumn{2}{|c|}{$\begin{array}{l}\text { The stages of designing } \\
\text { the appearance of } \\
\text { teaching materials }\end{array}$} & $\begin{array}{l}\text { Stages of } \\
\text { making } \\
\text { products }\end{array}$ \\
\hline \multicolumn{8}{|c|}{ 3. Expert Validation and Revision } \\
\hline \multicolumn{4}{|c|}{$\begin{array}{l}\text { Expert validation: Products are assessed by instructors } \\
\text { and material experts }\end{array}$} & \multicolumn{4}{|c|}{$\begin{array}{l}\text { Revision: based on findings on validation } \\
\text { results }\end{array}$} \\
\hline \multicolumn{8}{|c|}{ 4. Small-Scale Trials and Product Revisions } \\
\hline \multicolumn{6}{|c|}{$\begin{array}{l}\text { Trials: } \\
\text { 1) Five students use teaching materials in the form of Numbers Theory } \\
\text { as a learning resource } \\
\text { 2) Students complete questionnaires for teaching materials }\end{array}$} & \multicolumn{2}{|c|}{$\begin{array}{l}\text { Revision: Based on trial } \\
\text { input }\end{array}$} \\
\hline \multicolumn{8}{|c|}{ 5. Large-Scale Trials and Product Finalization } \\
\hline \multicolumn{5}{|c|}{$\begin{array}{l}\text { Trials: } \\
\text { 1) } 35 \text { students use textbook as learning resources } \\
\text { 2) Students complete the textbook assessment questionnaire }\end{array}$} & \multicolumn{3}{|c|}{$\begin{array}{l}\text { Revision: } \\
\text { based on trial input so that the final } \\
\text { product is obtained }\end{array}$} \\
\hline
\end{tabular}

Fig 1. Research and Development Procedures Scheme.

\section{Results and Discussion}

In accordance with the expected achievement plan, that in the first half of this year researchers have carried out the first step/phase to the third phase, namely expert validation and revision. The activity carried out at this stage is the researcher explores/studies which aim to gather more information about matters relating to the manufacture of products. The activities carried out in the first stage are exploratory/study researchers whose aim is to gather more information about matters relating to product manufacture. The study included analyzing the curriculum, learning achievement from the Number Theory course, Analyzing Material Number Theory, Analyzing students who took the Theory Number material and Analyzing the existing Number Theory references.

In the second step, the researcher develops the initial product which includes the preparation stage, the preparation stage of the teaching material, the design stage and the last stage is the stage of making the product. After that, it is continued in the third stage, namely expert validation and revision. In this third step, teaching material products are given an assessment by instructional materials experts and material experts and then revised based on the findings on the validation results.

\subsection{Curriculum Analysis}


The curriculum used in the mathematics education program Faculty of Teacher Training and Education University of Sarjanawiyata Tamansiswa is a curriculum that is aligned with the Indonesian National Qualification Framework ( INQF) in level 6. The description of the Level 6 in INQF is as follows. Able to apply their fields of expertise and utilize science, technology and/or art in their fields in solving problems and be able to adapt to the situation at hand. Mastering theoretical concepts of general knowledge and special theoretical concepts in these fields, and also able to formulate procedural problems. Being able to take the right steps produces an analysis of information and data, and is able to provide guidance in choosing various independent and group solution alternatives.

Responsible for own work and can be given responsibility for the results of the work of the organization. Curriculum documents and textbooks are based on certain pedagogical orientations, which are implicitly or explicitly discussed in them, and the teacher interprets the guidelines given in the textbook in ways that make sense to them [12]. A curriculum that is applied affects the learning resources used, prospective teachers, a number of contextual factors, and the teacher's response to these variables [13][14]. Mathematics refers to the content and nature of mathematical topics and practices that are emphasized and valued. This includes the ideas of certain content that is intended and how they are represented and involved and these are included in the Number Theory course. Textbooks are an important indicator of students' opportunities to learn because they reflect the curriculum intended for school [15][17]. This can provide prospective teachers with symbolic and analytical instruments that help them to develop their creativity and enable them to critically understand and solve problems and situations [18].

\subsection{Analysis of Learning Outcomes}

Number theory is an important part of all levels of mathematics education because understanding the Number Theory requires not only a deeper understanding of numbers that are usually obtained through experience with integers, as well as predictions for students' mathematical achievements a few years later [19][20]. So it is important to have learning achievement in the Number Theory course.

- Understand and apply the basic concepts of Division.

- Understand and apply the basic concepts of Kekongruenan.

Able to apply concept concepts related to division and integrity such as Fermat's Theorem, Wilson Theorem, Euler's Theorem.

\subsection{Student Analysis}

The Number Theory course is offered in the second semester. This course is one of the basic courses that must be mastered by prospective teachers. It is important to learn at the beginning of the semester because when prospective teachers gain the ability to mathematize everyday phenomena, they can recognize and extract mathematics embedded in certain situations by applying various techniques and a variety of mathematical tools to solve problems [18]. Plus they will teach some concepts in Number Theory in school mathematics. So that prospective teacher can better understand the critical conception of Number Theory which aimed to educate students about social conditions that affect their lives while using mathematics as one of the tools, among others [21]. 


\subsection{Material Analysis}

Number Theory Materials include:

- Mathematical Induction and Binomial Theorem

- Division

- Primes

- Congruence

- Fermat and Wilson theorem

- Arithmetic function

- Phi function and Euler theorem

- Primitive Root

\subsection{Reference Analysis}

References that are used as references in making textbook include:

- Sukirman. 2013. Number Theory. Yogyakarta: UNY Press.

- Yu Hing Bing. 2010. Problems of Number Theory in Mathematical Competitions. Shanghai: East China Normal Unversity Press.

- Kenneth Rossen. 1987. Elementary Number Theory and Its Application. California: Addison Wesley Publishing Company.

- Andrew Baker. 2009. Algebra and Number Theory. Published on website: http://www.maths.gla.ac.uk/ ajb. Department of Mathematics, University of Glasgow.

- Leo Moser. 2004. An Introduction to the Theory of Numbers. The Trillia Group: West Lafayette, IN.

- Alan Baker. 1964. A Concise Introduction to the Theory of Number. Cambridge University Press.

After the Step Developing Initial Product, the textbook was assessed by 4 validators who were lecturers of mathematics. Each validator reviews three main aspects, namely the aspect of content eligibility, the feasibility aspect of presentation and aspects of language feasibility. The average value of the validator review is 4.62 on a scale of 5 . This shows that the average validator review is in a very good category and required only a few revisions to be used in the Small Scale Trial step. The average score for each aspect is shown in Table 1.

Table 1. The average score of each review aspect

\begin{tabular}{lc}
\hline \multicolumn{1}{c}{ Aspect } & Average Score \\
\hline Content eligibility & 4.46 \\
Presentation feasibility & 4.67 \\
Language readability & 4.72 \\
\hline
\end{tabular}

Table 1. shows that the overall score for each aspect can be categorized as very good. The development of teaching materials is expected to help prospective teachers in achieving learning. The next stage of the plan is to start the fourth stage, namely the Small-scale Trial. The Small-scale Trial stage is based on the results of expert validation and is conducted on 5 prospective teacher students. Textbooks are an important influence on student learning experiences. Textbooks can affect students directly through their daily use in learning and indirectly the use of text also affects the teacher to guide instruction [15]. Based on empirical studies, when students are directly involved in learning activities they tend to get a high level of 
achievement and this can occur when textbooks can internalize information that is presented effectively [3][16].

\section{Conclusion}

Studies conducted at the exploratory study stage include analyzing the curriculum, analyzing the achievement of learning in Theory of Numbers, analyzing the material of Number Theory, analyzing students who take the material in Number Theory, and analyzing existing Number Theory references. In the third stage, expert validation suggests that the book in the category is very good in terms of content eligibility, the presenting feasibility and language readability can then be continued in the small-scale trial step.

\section{References}

[1] L. Haggarty and B. Pepin, "an Investigation of Mathematics Textbooks and Their Use in," Proc. 21-2 (British Soc. Res. into Learn. Math., vol. 21, no. July, pp. 117-125, 2001.

[2] L. L. Hadar, "Opportunities to learn: Mathematics textbooks and students' achievements," Stud. Educ. Eval., vol. 55, no. August, pp. 153-166, 2017.

[3] M. F. Sherman, C. Walkington, and E. Howell, "A Comparison of Symbol-Precedence View in Investigative and Conventional Textbooks Used in Algebra Courses," J. Res. Math. Educ., vol. 47, no. 2, pp. 134-146, 2016.

[4] M. Horsley, B. Knight, and H. Huntly, "The Role of Textbooks and Other Teaching and Learning Resources in Higher Education in Australia: Change and Continuity in Supporting Learning," IARTEM e-Journal, vol. 3, no. 2, pp. 43-61, 2010.

[5] D. Massey and L. Riley, "Reading Math Textbooks," vol. 56, no. April, pp. 577-586, 2013.

[6] L. Fan, Y. Zhu, and Z. Miao, "Textbook research in mathematics education: Development status and directions," ZDM - Int. J. Math. Educ., vol. 45, no. 5, pp. 633-646, 2013.

[7] F. Rahmawati, K. Komariah, and R. Auliana, "The Acquisition of Tacit Knowledge in Culinary Industry Work-Based Learning Process and Its Development Alternative," pp. 65-68, 2015.

[8] S. M. Towaf, "The National Heritage of Ki Hadjar Dewantara in Tamansiswa About Culture-Based Education and Learning," J. Educ. Pract., vol. 7, no. 23, pp. 167-176, 2016.

[9] A. Wijayanti and R. Utaminingsih, "the Development of Vii Grade Lesson Plan for Science Subject With 3N : Niteni, Nirokne, Nambahi ( To Inquire, To Copy, To Add ) Tamansiswa Approach With Outdoor Learning," Unnes Sci. Educ. J., vol. 6, no. 3, pp. 1686-1693, 2017.

[10] Depdiknas, Metode Penelitian Pengembangan. Jakarta: Badan Penelitian dan Pengembangan Departemen Pendidikan Nasional, 2008.

[11] M. D. Gall, W. R. Borg, and J. P. Gall, Educational research: An introduction. Longman Publishing, 1996.

[12] J. W. Son and O. K. Kim, “Teachers' selection and enactment of mathematical 
problems from textbooks," Math. Educ. Res. J., vol. 27, no. 4, pp. 491-518, 2015.

[13] J. T. Remillard and D. J. Heck, "Conceptualizing the curriculum enactment process in mathematics education," ZDM - Int. J. Math. Educ., vol. 46, no. 5, pp. 705-718, 2014.

[14] Dung Tran, Barbara J. Reys, Dawn Teuscher, Shannon Dingman, and Lisa Kasmer, "Analysis of Curriculum Standards: An Important Research Area," J. Res. Math. Educ., vol. 47, no. 2, p. 118, 2016.

[15] M. S. Polikoff, "How Well Aligned Are Textbooks to the Common Core Standards in Mathematics?," Am. Educ. Res. J., vol. 52, no. 6, pp. 1185-1211, 2015.

[16] A. K. Erbaş, C. Alacaci, and M. Bulut, "A comparison of mathematics textbooks from Turkey, Singapore, and the United States of America," Educ. Sci. Theory Pract., vol. 12, no. 3, pp. 2324-2330, 2012.

[17] J. Törnroos, "Mathematics textbooks, opportunity to learn and student achievement," Stud. Educ. Eval., vol. 31, no. 4, pp. 315-327, 2005.

[18] M. Rosa and D. C. Orey, "A trivium curriculum for mathematics based on literacy, matheracy, and technoracy: an ethnomathematics perspective," ZDM - Int. J. Math. Educ., vol. 47, no. 4, pp. 587-598, 2015.

[19] M. Gabel and T. Dreyfus, "Affecting the flow of a proof by creating presence-a case study in Number Theory," Educ. Stud. Math., vol. 96, no. 2, pp. 187-205, 2017.

[20] J. Torbeyns, M. Schneider, Z. Xin, and R. S. Siegler, "Bridging the gap: Fraction understanding is central to mathematics achievement in students from three different continents," Learn. Instr., vol. 37, pp. 5-13, 2015.

[21] E. Jablonka, "The evolvement of numeracy and mathematical literacy curricula and the construction of hierarchies of numerate or mathematically literate subjects," ZDM - Int. J. Math. Educ., vol. 47, no. 4, pp. 599-609, 2015. 